\title{
TINGKAT TUTUR DALAM BUDAYA 'JAWA' DAN 'BATAK': Analisis Sosio-Pragmatik
}

\author{
oleh Roswita Lumban Tobing
}

FBS Universitas Negeri Yogyakarta

\begin{abstract}
This article is about a socio-pragmatic study on the language used by the Javanese society which has some speech levels (or unggah-ungguh in Javanese) called ngoko, krama madya, and krama inggil and the language used by the Batak society which does not have such speech levels.

The difference concerning speech levels between the two societies is influenced by their traditional ways of living. The traditional Javanese society is divided into two levels: the priyayi (or the nobility) and wong cilik (or the commoner) levels. A priyayi uses ngoko in communicating with a wong cilik but the latter cannot use it in communicating with the former. In such a case, the wong cilik uses krama inggil. This seems to indicate that solidarity in the Javanese society is poor. On the other hand, the Batak society does not have such levels so that there are no speech levels in its language. Though the Batak society has many margas, which means that any members of the society having the same last name belong to the same marga and are regarded as members of the same family (the relevant term is dongan sabutuha), they are obliged to help other people who do not belong to their marga because the philosophy of the Batak society is dalihan na tolu, which explains that solidarity in the Batak society is very important.
\end{abstract}

Keywords: socio-pragmatic, ways of living, speech levels, solidarity

\section{A. PENDAHULUAN}

Salah satu fungsi utama komunikasi adalah untuk menjaga keberlangsungan hubungan antara komunikannya. Oleh karena itu, bahasa yang merupakan alat komunikasinya berisi kaidah-kaidah yang mengatur bagaimana cara seseorang bertutur agar hubungan interpersonal para pemakai bahasa tersebut dapat terpelihara dengan baik. Dalam kaitan ini, masyarakat pengguna bahasa, dalam situasi tertentu dan untuk mencapai tujuan tertentu, akan selalu berusaha memilih dan menggunakan kaidah-kaidah tuturan (utterance) yang sesuai dengan situasi pertuturan agar peserta tutur dapat saling berinteraksi, dan bentuk tuturnya menjadi saling terpahami. Pemahaman terhadap tutur tersebut, menurut teori etnometodologi (Richards dkk. 1985: 97) dimungkinkan karena adanya pengetahuan bersama (shared knowledge) diantara penutur dan petutur.

Kaidah-kaidah dalam tata cara berkomunikasi, berbeda antara suatu masyarakat dengan masyarakat lainnya. Dalam studi sosio-pragmatik, dapat dilihat bahwa strategi bertutur yang disebut dengan retorika dalam prinsip sopan santun, pada kebudayaankebudayaan dan masyarakat bahasa yang berbeda misalnya, akan beroperasi secara berbeda (Leech, 1993: 15). Sebagai contoh, dalam masyarakat Jawa yang memiliki tingkat tutur 'unggah-ungguh' (ngoko, madya atau krama inggil), penggunaannya dipilih penutur ketika berbicara dengan petutur sesuai dengan situasi interaksi tertentu (Adisumarto, 1991 : 26). Demikian pula pada masyarakat Batak, pemilihan tingkat tutur yang terjadi pada masyarakat Batak Toba ini juga disesuaikan 
dengan situasi interkasi tertentu, namun situasi interkasi dalam masyarakat budaya Jawa berbeda dengan masysrakat budaya Batak. Perbedaan ini dipengaruhi oleh latar sosial budaya kedua masyarakat tersebut. Hal ini menarik perhatian penulis untuk menyelusuri strategi bertutur masyarakat yang berbahasa Batak Toba dan masyarakat yang berbahasa Jawa, dalam upaya menjaga dan mempertahankan hubungan sosial yang berlaku ditengah masyarakatnya.

\section{B. PENGERTIAN BUDAYA}

Pengertian Budaya menurut Farr dan Ball (1999: 206) adalah pengetahuan yang dimiliki oleh sekelompok masyarakat, yang berkaitan dengan perilaku mereka. Selanjutnya menurut kamus besar bahasa Indonesia, budaya adalah hasil kegiatan dan penciptaan akal budi manusia, misalnya kesenian, kepercayaan dan adat istiadat. Dari pemaparan tersebut, dapat dikatakan bahwa budaya akan selalu berkaitan dengan cara hidup sekelompok masyarakat, termasuk cara anggota masyarakat budaya itu berkomunikasi atau bertutur. Hal tersebut sesuai dengan pendapat Goodenough (dalam Geertz, 1973: 11) bahwa budaya adalah hal-hal yang perlu diketahui dan dipercayai oleh seseorang agar ia dapat bertingkah laku dengan cara yang berterima dalam kelompok masyarakatnya.

Horton (1987: 64-66) menjelaskan bahwa budaya menentukan standar prilaku, karena budaya adalah sistem norma yang mengatur cara-cara merasa dan bertindak yang diketahui dan diikuti oleh anggota masyarakatnya. Penerapan norma-norma tersebut telah menjadi kebiasaan bagi anggotanya karena dilaksanakan berulang-ulang, dan normanorma tersebut menjadi lazim bagi mereka. Dari norma-norma yang dimiliki itu, kemudian kelompok masyarakat dapat mengetahui bentuk perilaku dan tindak tutur yang menunjukkan budaya kesopanan, hal yang baik dan yang tidak yang berhubungan dengan kebiasaan, demikian pula dalam hal strategi bertutur, karena cara hidup (ways of living) sekelompok masyarakat akan selalu berdampingan dengan cara bertindak tutur atau berkomunikasi (ways of communicating) masyarakat yang bersangkutan.

\section{PRAGMATIK}

Studi pragmatik berpusat pada penggunaan bahasa dalam suatu situasi ujar yang berhubungan dengan retorika. Hal ini sejalan dengan pendapat Leech (1993: 22-24) yang menjelaskan bahwa retorika adalah keterampilan penggunaan bahasa dalam komunikasi sehari-hari. Salah satu dari bentuk retorika yang dikemukakan oleh Leech (1993: 205) adalah retorika interpersonal. Dalam retorik interpersonal terdapat prinsip-prinsip komunikasi, salah satu diantaranya adalah prinsip bertindak tutur yang berterima dalam suatu masyarakat, yang merupakan salah satu bentuk kesopanan. Namun, tingkat penggunaan maksim-maksim pada prinsip tindak tutur masing-masing kelompok masyarakat, seperti yang telah diutarakan sebelumnya, berbedabeda dari suatu budaya ke budaya yang lain.

Brown dan Levinson (dalam Gunarwan, 2004: 5-6) mengutarakan lima strategi bertutur, yaitu (1) bertutur dengan cara berterus terang tanpa menggunakan bentuk basa-basi, (2) bertutur dengan cara terus terang dengan menggunakan bentuk basa-basi, yang berupa kesantunan positif, yang mengacu pada keinginan seseorang agar hal yang diasosiasikan dengan dirinya dinilai baik oleh orang lain, (3) bertutur dengan cara terus terang dengan menggunakan bentuk basa-basi yang berupa kesantunan negatif, yang mengacu pada keinginan seseorang agar tindakannya tidak diganggu oleh orang lain, (4) bertutur tidak secara terang-terangan, dan (5) bertutur di dalam hati.

Sejalan dengan pendapat para ahli di atas, Sperber dan Wilson (dalam Wijana 2004: 3) mengatakan bahwa komunikasi akan berjalan lancar, jika penutur mematuhi prinsip relevansi. Ukuran relevansinya adalah apakah tindakan penutur mempunyai efek kognitif dalam benak penutur. Efek kognitif tersebut adalah efek kontekstual yang terdapat pada sistem kognitif petutur. Semakin kuat efek 
kognitif yang dimiliki, semakin relevan pula informasi yang disampaikan oleh petutur. Menurut Sperber dan Wilson informasi yang tersirat : tidak dikatakan, tetapi dikomunikasikan oleh petutur dalam suatu percakapan (implikatur), dapat diidentifikasikan berdasarkan prinsip relevansi, yaitu berdasarkan harapan petutur : apakah ujaran penutur secara optimal relevan atau tidak.

Sosio-pragmatik menjelaskan mengapa pada interaksi tertentu penutur memilih dari khasanah linguistiknya suatu bentuk bahasa. Sosiolinguistik, misalnya akan menjelaskan bahwa masing-masing bahasa memiliki pemarkah kesantunan. Pemarkah tersebut akan tampak pada variasi bentuk satuan-satuan lingualnya. Pemilihan bentuk bahasanya berdasarkan komponen tindak atau peristiwa tutur Hymes (SPEAKING). Dalam Pragmatik pemarkah tersebut tampak pada strategi-strategi yang ditempuh oleh penuturnya pada saat memproduksi berbagai tipe tuturan (Wijana, 2004:1). Salah satu ciri khas tipe tuturan ini adalah tujuan masyarakat peserta petuturan, bukan tujuan peristiwa tutur seperti yang terdapat pada model Hymes. Sehubungan dengan hal itu dapat dikatakan bahwa pragmatik adalah kajian tentang strategi bertutur.

Dari penjelasan di atas dapat dikatakan bahwa sosio-pragmatik mejelaskan strategistrategi berkomunikasi yang seharusnya dan yang biasa dilakukan oleh para pemakai bahasa dalam upaya menjaga dan mempertahankan hubungan sosial yang berlaku pada masyarakatnya. Dengan kata lain, sosiopragmatik menjelaskan bagaimana cara kelompok-kelompok masyarakat bahasa menunjukkan perbedaan-perbedaan tindak tutur dalam upaya penerapan prinsip sopan santun dalam budaya masyarakat tersebut.

\section{STRATEGI BERTUTUR DALAM BUDAYA'JAWA' DAN 'BATAK'}

Seperti yag telah dipaparkan di atas bahwa pragmatik sangat berkaitan dengan cara masyarakat tutur (speech community) menggunakan bahasa mereka : bagaimana tindak tutur dilakukan dalam suatu peristiwa tutur, yaitu secara langsung atau tidak langsung, perlu tidaknya pemakaian strategi kesantunan, perlu atau tidak daya (force) dalam tindak tutur yang diungkapkan melalui implikatur. Penggunaan bahasa yang melibatkan hal tersebut di atas diatur oleh nilai-nilai kebudayaan masyarakat yang bersangkutan. Disini tampaklah hubungan antara pragmatik dengan budaya dan penggunaan bahasa oleh suatu kelompok masyarakat. Dengan kata lain dapat dikatakan bahwa budaya mengatur penggunaan bahasa. Hal tersebut akan tampak lebih jelas pada uraian mengenai strategi bertutur masyarakat Jawa dan masyarakat Batak berikut ini.

Penggunaan bahasa (tindak tutur) pada kalangan suku Jawa berbeda dengan tindak tutur pada kalangan suku Batak. Pandangan hidup yang merupakan bagian dari kebudayaan kedua suku tersebut berbeda. Suku Batak lebih sering menggunakan strategi bertutur dengan cara terus terang, sedangkan suku jawa lebih sering menggunakan strategi bertutur dalam hati. Menurut hasil penelitian Gunarwan (Gunarwan, 2004: 13), strategi pengungkapan tindak tutur melarang yang paling sering digunakan oleh suku Batak adalah bentuk 'terus terang tanpa basa-basi', dan tindak tutur melarang yang paling sering digunakan suku Jawa adalah 'di dalam hati'. Temuan ini menunjukkan bahwa budaya Batak 'menggalakkan' suku batak untuk lebih berani melarang dengan secara terus terang. Sebaliknya budaya Jawa 'menggalakkan' suku Jawa lebih memilih diam.

Selanjutnya, dapat dijelaskan bahwa perbedaan strategi bertutur kalangan masyarakat Batak dan kalangan masyarakat Jawa dipengaruhi oleh pandangan tradisionalnya. Dalam pandangan tradisional masyarakat Batak yang terbagi dalam marga-marga, setiap orang Batak merupakan anggota dari suatu marga, oleh karena itu sekelompok masyarakat yang memiliki marga yang sama akan menjadi 'dongan sabutuha' (saudara dari keturunan marga yang sama). Implikasinya adalah bahwa semua anggota dari marga yang sama adalah 
keluarga. Hubungan antara mereka tidak dapat dipisahkan. Selain itu, adat kalangan masyarakat Batak mewajibkan agar anggota suatu marga membantu anggota kelompok marga yang lain. Hal ini berdasarkan pandangan tradisional masyarakat Batak yaitu 'dalihan na tolu' (tungku tiga), (Sihombing, 1986:74-75) yang mengumpamakan solidaritas masyarakat Batak sebagai api yang harus ada agar tungku yang digambarkan pada 'dalihan na tolu' tersebut dapat berfungsi dengan baik. Dari sini tampak bahwa solidaritas sangat penting bagi masyarakat Batak, seperti yang terdapat dalam peribahasa: 'Suhar bulu ditait dongan, laos suhar do I taiton'. Peribahasa ini menunjukkan bahwa permasalahan yang dialami oleh seorang teman akan menjadi permasalahan pula bagi teman yang lainnya.

Di samping solidaritas antarmarga, menurut Simatupang (dalam Gunarwan, 2004: 8), masyarakat Batak juga tidak membedakan kelas sosial. Hal ini tampak pada upacara adat misalnya, seorang bupati harus 'mangulosi' (memberi selendang sebagai bentuk rasa hormat, menghargai atau memberkati) seorang tukang kebun dalam upacara pernikahan yang diadakan suatu kelompok marga. Acara 'mangulosi' ini tidak menurunkan harga diri seorang bupati yang memiliki status sosial (non-adat) yang sangat tinggi jika dibandingkan dengan seorang tukang kebun. Struktur sosial ini tercermin pada bentuk tuturan dalam bahasa Batak, seperti pada contoh berikut.

\section{1. jalo hamuma ulos tondion}

(Terimalah selendang ini, sebagai penghangat dalam kehidupanmu)

2. Bolgama atemuna manjalo hian mason sian hami boru

(Terimalah ikan mas ini, sebagai tanda hormat kami, pihak perempuan)

3. Nionma upa-upa sian hami, hula-hula, tu borunami .

(Terimalah tanda kasih dari kami, yang merupakan keluarga besar laki-laki dari istri, untuk keluarga besar menantu kami)

4. Horas bah! andigan hamu sahat dison?
(Selamat bertemu ! kapan (kamu) tiba disini?)

5. Molo boi, naeng tu jabumuna do ahu marsogotbah.

(Kalau bisa, saya mau kerumahmu besok)

6. Naeng tudia do hamu bah?

(Kamu mau kemana?)

Tuturan (1) di atas akan diujarkan oleh seorang bupati kepada seorang tukang kebun, ketika bupati tersebut 'mangulosi' tukang kebun. Seorang tukang kebun juga akan mengujarkan tuturan yang sama kepada seorang bupati ketika tukang kebun tersebut 'mangulosi' bupati pada suatu acara adat. Demikian pula pada tuturan (2), pada acara adat pernikahan, biasanya tuturan ini selalu digunakan oleh keluarga besar dari istri 'hulahula' pada saat memberikan 'upa-upa' kepada pihak keluarga besar menantu 'boru', dan tuturan (3) menunjukkan bahwa pihak menantu juga menghormati 'hula hula', yaitu dengan cara memberi 'hian mas' (ikan mas), tanpa melihat kelas sosial kehidupannya. Tuturan (4), (5) dan (6) diujarkan pada situasi ujar tertentu yang tergantung pada faktor yang relatif permanen, antara lain derajat keakraban, status atau kedudukan dan usia (Leech,1993: 199). Faktor keakraban pada tuturan (4), (5) dan (6) tampak pada penggunaan partikel ' $b a h^{\prime}$. Faktor status atau kedudukan tidak tampak pada ketiga tuturan tersebut, tuturan itu dapat diujarkan oleh seorang sopir kepada seorang dokter. Sedangkan faktor usia tidak terlalu berpengaruh, karena tuturan tersebut bisa diujarkan oleh seseorang yang berusia mudah kepada seseorang yang berusia tua, atau seorang yang berusia tua kepada seorang yang berusia muda.

Bagi masyarakat Batak, menurut Sihombing (1986: 71-72), keseimbangan untuk kelangsungan hidup berasal dari falsafahfalsafah Batak berikut ini.

\section{a. Banua na tolu (tiga bagian dunia)}

Menurut falsafah masyarakat Batak, alam semesta ini terdiri atas tiga bagian, yaitu (1) banua ginjang (dunia bagian atas), (2) 
banua tonga (dunia bagian tangah), dan (3) banua toru (dunia bagian bawah). Walaupun demikian, ketiga bagian dunia tersebut tidak menunjukkan perbedaan derajat, yang berbeda adalah jenis penghuninya.

\section{b. Bonang na tolu (benang yang terdiri atas tiga jenis pilinan)}

Dalam masyarakat Batak kesatuan sosial dilambangkan dengan tiga pilin benang yang masing-masing warnanya adalah putih, merah dan hitam. Warna-warna yang terdapat pada bonang na tolu ini melambangkan tiga unsur utama di dalam masyarakat Batak.

\section{c. Dalihan na tolu ( tungku yang memiliki penyanggah tiga buah)}

Dalihan na tolu ini merupakan falsafah yang paling penting bagi masyarakat Batak. Falsafah ini sangat berkaitan dengan kehidupan sehari-hari. Penerapan mekanisme 'dalihan na tolu' 'Tiga' yang dimaksud disini adalah tiga buah batu yang digunakan sebagai tungku untuk menyanggah belanga penanak nasi. Belanga tempat menanak nasi ini harus selalu dalam keadaan seimbang, dan untuk itu batu penyangganya harus tiga (batu). Letak ketiga penyangga tersebut harus disusun dengan baik, dengan jarak yang sama antara penyangga yang satu dengan penyangga lainnya agar kekuatan untuk menahan berat belanga dapat terjaga dengan baik. Disamping itu, ketiga penyangga juga harus berukuran sama, untuk menjaga keseimbangan letak belanga. Hal inilah yang menunjukkan asal mula persamaan derajat yang dianut oleh masyarakat Batak. Bagi masyarakat Batak derajat semua warga adalah sama, yang berbeda adalah tugas dan fungsi masing-masing warga dalam suatu keperluan. Seperti yang dikatakan oleh Simatupang (1989: 5-6) bahwa falsafah dalihan na tolu has lent the Batak society a flavor of democracy. It is an egalitarian society which has never produced a highly hierarchically organized from government... (it) counteracts any attempt or satu bahasa, tingkat tutur masyarakat Batak tidak hierarkis dan masyarakat Batak adalah masyarakar yang egaliter.

Sebaliknya, menurut masyarakat Jawa, kehidupan mereka sudah ditentukan 'dari sana', kekuasaan yang didistribusikan kepada mereka sudah dijatah, oleh karena itu setiap orang dalam masyarakat Jawa harus 'nrima in pandum' (menerima apa yang diberikan padanya), walaupun distribusi kekuasaan itu tidak merata dan mengakibatkan ketidaksamaan derajat. Pandangan hidup masyarakat Jawa ini telah membentuk mereka menjadi masyarakat yang berlapis-lapis.

Masyarakat Jawa tidak memiliki marga, tetapi dalam kehidupannya, masyarakat jawa memiliki dua strata : (1) priyayi (bangsawan) dan (2) wong cilik (rakyat jelata). Oleh karena itu, bentuk tuturan dalam budaya masyarakat Jawa terbagi dalam 4, yaitu : (a) ngoko, (b) ngoko alus, (c) krama, dan (d) krama alus (Sudaryanto, 1991: 5). Dalam budaya Jawa, seorang bangsawan melayani seorang rakyat jelata bukanlah suatu hal yang lazim, dan merupakan penurunan derajat. Jika seorang 'ndara' (tuan) menggunakan bentuk 'krama alus' pada saat berkomunikasi dengan pembantunya, bukan bentuk 'ngoko' sebagaimana lazimnya, hal ini bisa terjadi karena 'ndara' tersebut mempunyai tujuan tertentu, misalnya ingin menyindir atau sedang marah kepada pembantunya. Dalam hal ini sang 'ndara' menerapkan prinsip ironi ketika bertutur dengan pembantunya. Prinsip ironi adalah 'second-order principle' yang dibangun atas prinsip sopan santun. Secara umum prinsip ironi ini menurut Leech (1993: 125) mengandung makna bahwa :

kalau anda terpaksa menyinggung perasaan petutur, usahakanlah agar tuturan anda tidak berbenturan dengan prinsip sopan santun (PS) secara mencolok, biarlah petutur memahami maksud tuturan anda secara tidak langsung, yaitu melalui implikatur. 
pada contoh berikut ini, yaitu ujaran yang dituturkan oleh seorang 'ndara' kepada pembantunya.

7. Badhe tindakan to?

(Mau jalan-jalan ya?)

8. Nembe ngaso to?

(Lagi istirahat ya?)

Pada contoh (7) dan (8) di atas, jika tuturan tersebut diujarkan oleh seorang 'ndara' kepada pembantunya, maka implikatur dari prinsip ironinya adalah bahwa tuturan tersebut sangat sopan, tetapi untuk tujuan yang tidak benar, yaitu untuk menyindir si pembantu atau untuk menunjukkan bahwa sang bangsawan melarang si pembantu kegiatan tindakan (jalanjalan) dan ngaso (istirahat). Bentuk Tuturan (7) dan (8) ini merupakan salah satu strategi bertutur masyarakat Jawa, yaitu dengan menggunakan bentuk ketaklangsungan, yang dalam teori Trosborg termasuk dalam strategi ketiga : bertutur dengan cara terus terang dengan menggunakan bentuk basa-basi. Dengan kata lain, tuturan ini merupakan salah satu cara untuk melunakkan daya ilokusi agar dampak tuturan tidak sekeras dampak tuturan yang diujarkan tanpa basa-basi. Hal ini menunjukkan bahwa solidaritas di kalangan masyarakat Jawa relatif rendah. Disamping itu, kelas sosial dalam kehidupan bermasyarakat masih sangat berpengaruh, seperti yang tampak pada contoh-contoh berikut.

9. Nyuwon pangapunten, menawi bapak kagungan wedhal, kulo badhe sowan bapak benjang sonten.

(Maaf, jika bapak ada waktu, saya ingin ketemu bapak besok sore)

10. Nek kono ono wektu, aku arep nenggonmu sesoksore.

(Kalau kamu ada waktu, saya mau ke rumahmu besok sore)

11. Ibu tindak wonten pundi?

(Ibu pergi kemana?)

12. Kowe arep nengendi?

(Kamu mau pergi kemana?)

Tuturan (9) dan (11) di atas, jika dilihat dari strata masyarakatnya, tidak mungkin diujarkan oleh seorang bangsawan 'priyayi' kepada seorang rakyat jelata 'wong cilik', walaupun usia rakyat jelata itu lebih tua dari usia si bangsawan. Namun sebaliknya, tuturan (10) dan (12) sudah pasti diujarkan oleh seorang priyayi kepada seorang wong cilik. Hal ini terjadi karena budaya masayarakat Jawa yang menentukan bahwa 'krama alus' dipergunakan oleh seseorang yang berstrata rendah terhadap seseorang yang berstrata tinggi (Adisumarto, 1991:26).

Bagi masyarakat Jawa hal yang perlu dipertimbangkan oleh peserta petuturan bila hendak berbicara sopan dengan orang lain, untuk memelihara kerukunan sosial, dijabarkan dalam maksim-maksim sebagai berikut (Gunarwan, 2004: 7).

\section{a. Kurmat (menghormati orang lain)}

Masyarakat Jawa, dalam kehidupan sosialnya, menggunakan maksim kurmat (menghormati orang lain). Maksim ini menggambarkan bahwa untuk menjaga kerukunan dalam bermasyarakat, seseorang diharapkan dapat menghormati dan tidak memandang rendah orang lain. Berikut contohcontoh dari tuturan yang diujarkan oleh seorang direktur kepada karyawannya, yang menggunakan maksim kurmat.

13. Mbak saget nglebetke data niki teng komputer?

(Mbak bisa memasukkan data ini ke komputer?)

14. Mas, mengke tulung ditelponke Pak Basri nggih?

(Mas, nanti tolong telephon ke Pak Basri ya?)

Tuturan (13) dan (14) di atas, merupakan bentuk tuturan dalam bahasa Jawa dalam ragam non formal dan menggunakan bentuk sapaan 'mbak' dan 'mas' yang menunjukkan salah satu bentuk rasa hormat kepada orang yang disapa. Selain itu, pada tuturan (13) tersirat ketaklangsungan : kalimat interrogatif untuk tujuan perintah, yaitu menyuruh untuk memasukkan data ke komputer (perintah/permintaan seorang direktur kepada bawahannya). Selanjutnya, pada tuturan (14), selain penggunaan bentuk 
sapaan 'mas', penutur juga menggunakan kata 'tulung', yang menunjukkan bahwa bentuk tuturan tersebut adalah sebuah permintaan dengan tujuan memberi perintah, seperti pada tuturan (13).

\section{b. Andhap asor ( rendah hati)}

Maksim andhap asor (rendah hati) ini menggambarkan bahwa masyarakat jawa akan selalu menghindari untuk memuji diri sendiri, (bandingkan dengan teori maksim kerendahan hati oleh Leech). Tuturan-tuturan berikut adalah contoh prinsip sopan santun dari maksim ini.

\section{Tiang menika sae sanget, kersa ambiantu} dateng kula.

(Orang itu baik sekali, mau membantu saya)

16. Mugi panjenengan kersa nampi cecaosan dalem egkang boten sepinten punika.

(Terimalah pemberian saya yang tidak berharga ini)

17. Kula rumaos cubluk, kirang pangertosan

(Saya merasa bodoh, kurang mengerti)

Tuturan (15) di atas termasuk dalam ragam formal yang menunjukkan sopan santun, karena tuturan tersebut bertujuan untuk memuji orang lain. Demikian pula tuturan (16) dan (17) sopan karena menunjukkan kerendahan hati.

\section{c. Empan papan (bisa menempatkan diri)}

Maksim ini tampak pada salah satu tindak tutur yang dilakukan oleh seseorang kepada orang lain yang berusia lebih tua darinya, seperti pada contoh- contoh berikut ini.

18. Nyuwunsewu, bapak dipunaturi lenggah wonten lajengan

(Maaf, bapak dimohon untuk duduk di depan)

19. Kula lenggah wonten wingkingipun bapak mawon

(Saya duduk di (kursi) belakang bapak saja)

Selain contoh tuturan (18) dan (19) di atas, maksim ini juga menunjukkan bahwa masyarakat Jawa dapat menempatkan dirinya sesuai dengan stratanya, seperti yang telah dijelaskan pada uraian sebelumnya. Berikut contoh tuturan yang menunjukkan penggunaan maksim empan papan (bisa menempatkan diri) berdasarkan strata masyarakat Jawa.

\section{Kula boten wantun celak kalian ibu bupati}

(Saya tidak berani dekat dengan ibu bupati)

Tuturan (20) menunjukkan bahwa 'ibu bupati' adalah 'priyayi' dan tuturan ini diujarkan oleh seorang biasa 'wong cilik'.

\section{d. Tepa selira (tenggang rasa)}

Penggunaan maksim tepa selira (tenggang rasa) ini dapat dilihat pada contohcontoh tuturan berikut ini.

\section{Mangga embah, lenggahipun}

(Silahkan duduk nek)

22. Mriki kula betaken tasipun ibu

(Mari saya bawakan tasnya bu)

Tuturan (21) pada situasi tertentu, misalnya dalam bis umum, akan menjadi sangat sopan jika diujarkan oleh seseorang yang berusia muda kepada seorang 'embah' (nenek). Demikian pula pada tuturan (22) misalnya, seorang pemuda tidak hanya berpangku tangan pada saat ia melihat seorang ibu yang berada di dekatnya membutuhkan bantuan, membawakan tasnya yang kelihatan berat. Pemuda tersebut akan mengujarkan tuturan (22) ini untuk tujuan membantu ibu itu. Dari penjelasan ini dapat dikatakan bahwa tuturan (21) dan (22) tersebut menunjukkan bahwa dalam kehidupan sosialnya seseorang telah menggunakan maksim tepa selira (tenggang rasa).

Keempat maksim ini (kurmat, andhap asor, empan papan dan tepa selira) saling berkaitan satu sama lainnya. Ketika seseorang menggunakan maksim kurmat, maka orang itu juga telah menggunakan empan papan, seperti yang terdapat pada tuturan (18) : 'Kula lenggah wonten wingkingipun bapak mawon'. Maksim kurmat pada tuturan ini tampak pada bentuk sapaan 'bapak' dan maksim empan papan tampak pada 'lenggah wonten wingkingipun'. Demikian pula ketika seseorang menggunakan maksim empan papan, ia juga menggunakan maksim tepa selira. Hal tersebut dapat dilihat pada tuturan (21): 'Mangga embah, 
lenggahipun'. Maksim empan papan dan maksim tepa selira tampak pada tuturan tersebut secara keseluruhan.

Dari uraian dan contoh-contoh tuturan di atas, dapat dikatakan bahwa perbedaan struktur sosial tercermin pada kedua budaya tersebut (budaya Batak dan budaya Jawa). Berbagai bentuk tuturan, yang merupakan strategi bertutur yang digunakan oleh penutur pada saat berinteraksi dengan lawan tuturnya, akan mencerminkan bentuk hubungan sosial dan budaya antara penutur dan lawan tuturnya. Dengan kata lain, budaya akan mempengaruhi penggunaan bahasa oleh sekelompok masyarakat, seperti yang diuraikan di atas, yaitu contohcontoh tuturan oleh masyarakat Jawa, didasarkan pada tiga parameter pragmatik, yaitu jauh dekatnya hubungan penutur dan lawan tutur, status sosial penutur dan tingkat tindak tutur yang dipilih, dan penggunaan tingkat tindak tutur masyarakat Batak tidak membedakan derajat antara warga masyarakatnya.

Perbedaan tindak tutur antara masyarakat Jawa dan masayarakat Batak tersebut akan berpengaruh terhadap kedua masayarakat pengguna bahasa, jika mereka saling berhubungan baik dalam berkomunikasi maupun dalam pergaulan sehari-hari, dan hal ini akan sangat terasa bagi masayarakat Jawa yang priyayi, karena masayarakat priyayi terbiasa dengan tuturan-tuturan kromo alus, jika bersentuhan dengan masyarakat Batak yang tidak memiliki tindak tutur yang hierarkis, dapat menimbulkan rasa tidak nyaman. Demikian pula sebaliknya bagi masyarakat Batak yang akan merasa aneh jika dalam bertutur dengan masyarakat Jawa, mereka mendengar kata 'ndara' (tuan) untuk menyapa.

Sehubungan dengan hal tersebut, dalam berinteraksi penutur dan lawan tutur, baik masayarakat Jawa maupun masayarakat Batak, perlu mempertimbangkan agar bentuk tuturan-tuturan yang digunakan tidak menyimpang dari prinsip-prinsip kesopanan yang merupakan kebiasaan dan menjadi lazim menurut budaya masing-masing kelompok masyarakat. Disamping itu, masyarakat kedua bahasa tersebut juga sebaiknya berusaha untuk saling memahami perbedaan-perbedaan kebudayaannya.

\section{E. PENUTUP}

Berdasarkan pembahasan yang telah diuraikan di atas dapat diambil kesimpulan sebagai berikut.

1. Penggunaan tingkat tutur dalam bahasa Batak tidak bersifat hierarkis. Sebaliknya, dalam bahasa Jawa penggunaan tingkat tutur untuk menunjukkan derajat si petutur atau orang yang menjadi topik tuturan.

2. Berdasarkan hubungan para anggota masyarakatnya, derajat solidaritas dikalangan masyarakat Batak lebih tinggi dari derajat solidaritas di kalangan masyarakat Jawa. Oleh karena itu, dapat dikatakan bahwa Hubungan di antara anggota masyarakat Batak pada umumnya adalah hubungan yang equal dan solidary. Hubungan di antara anggota masyarakat Jawa pada umumnya adalah hubungan nonequal dan non-solidary

\section{DAFTAR PUSTAKA}

Adisumarto, Mukidi. 1991. Unggah -ungguh Bahasa Jawa Modern. Balai Sejarah Tradisional dan Javanologi Yayasan Panunggalan: Yogyakarta

Farr M. dan A.F.Ball. 1999. Standard English. Dalam Spolsky.B 205208

Geertz, Clifford. 1973. The Interpretation of Cultures. Princoton: Basil Books

Gunarwan, Asim. 2004. Pragmatik, Budaya dan Pengajaran Bahasa. Makalah Seminar Nasional Semantik III, UNS : Surakarta

Horton, Paul B. dkk. 1984 Sosiologi. Terjemahan Aminuddin Ram dan Tina R. Jakarta: Erlangga

Leech, Geoffrey. 1993. Prinsip-Prinsip Pragmatik. Terjemahan Dr. M.D.D. Oka, M.A. Jakarta : UI Press

Richards, Jack. 1990. Interchange. Cambridge : Cambridge University Press 
Sihombing, T.M. 1986. Filsafat Batak. Jakarta : Balai Pustaka

Simatupang, Maurits.1989. The life of the Batak. Makalah. Ganesha Tuesday Evening Lecture Series. Erasmus Huis. Jakarta.
Sudaryanto.1991. Tata Bahasa Baku Bahasa Jawa. Yogyakarta : Duta Wacana University Press

Wijana, I Dewa Putu. 2004. Teori Kesantunan dan Humor. Makalah Seminar Nasional Semantik III, UNS : Surakarta 